\title{
The Personality of Javanese Leaders in the Manuscript of Nitik Kanjeng Ratu Pambayun
}

\author{
Agatia Mega Rianda*, Endang Nurhayati \\ Faculty of Language and Art, Universitas Negeri Yogyakarta, Indonesia \\ "Corresponding author.Email: agatiamega99@gmail.com
}

\begin{abstract}
The Nitik Kanjeng Ratu Pembayun manuscript is one of the collections of the Yogyakarta Sonobudoyo Library with the code PB C.71. In the manuscript is written the genealogical history of Kanjeng Ratu Pambayun, daughter of Pakubuwana 7 of GKR Pakubuwana. The lineage of his father and mother begins with the last Prabu Brawijaya in Majapahit. The manuscript also describes the leaders at that time whose personality can be an example for today. The aim of this study is to explain the personality of the Javanese leader in the manuscript of Nitik Kangjeng Ratu Pambayun. This is qualitative descriptive research in which the data are lines or sentences that describe the personality of the Javanese leader in the manuscript of Nitik Kangjeng Ratu Pambayun. The data source of this research is the manuscript of Nitik Kangjeng Ratu Pambayun. The collecting data method of this research is using philological research. The data analysis method is by descriptive analysis method and heuristics, and literary hermeneutics. The validating method in this research is by using semantic validity, while the reliability was conducted by using intrarater reliability. The result of this research shows the personality of Javanese leaders based on the manuscript of Wulangreh contained in the manuscript of Nitik Kanjeng Ratu Pembayun. The personality of the Javanese leaders based on the manuscript of Wulangreh contained in the manuscript of Nitik Kangjeng Ratu Pambayun is wise, patient, smart in all things, responsible, compassionate, fair, tolerant, and trustworthy.
\end{abstract}

Keywords: Javanese leader, Kanjeng ratu pambayun, manuscript, philology, personality

\section{INTRODUCTION}

Manuscript is a concrete object of research in various fields of science such as philology, history, archaeology, codicology, and paleography [1]. Therefore, literary works in the form of manuscripts must be maintained and preserved so that they can be used to increase knowledge for readers about the content contained in the manuscript. With the existence of literary works, especially manuscripts that are sustainable, they can provide great benefits for their readers. Because it can be used as an object of research studies and can increase knowledge.

Some values that exist in the present are actually related to values that have existed in the past [2]. Thus, the development of the nation and society today can be known and developed by taking into account its historical basis. From the explanation above, it can be concluded that until now there are still many historical writings in the form of manuscripts that are stored and can be a source of knowledge today. Historical writings in the form of manuscripts contain education, leadership, politics, morals, the history of the Javanese king, health and so on.

These various manuscripts have become a legacy that is owned by Indonesia. One of them is a Javanese script and a Pegon script. Manuscripts in the archipelago contain a lot of knowledge [3]. Science is related to human life such as social, political, economic, religious, cultural, language and literature. Of course, the knowledge contained in the manuscript can be an example today. Manuscripts as Indonesian cultural heritage are stored in many museums, regional libraries, national libraries, and international libraries. There are also some manuscripts that are kept as private property or individuals.

Many of the manuscripts in the archipelago use the Javanese language It is in line with [4] that the Javanese 
language had developed in its era, from old Javanese, middle Javanese, and the recent modern Javanese language. In reality, not many people know that manuscripts contain historical elements, because many people cannot read the script and cannot understand the language used in the manuscript [5]. Thus, the philological research that has been carried out by several students certainly makes it easier for readers to find out what knowledge is contained in the manuscript.

The manuscript with the title Nitik Kangjeng Ratu Pambayun, hereinafter abbreviated as NKRP, is one of the interesting manuscripts to be studied. The basis for the selection of the manuscript is that the NKRP manuscript contains important things, namely lessons related to the personality of Javanese leaders that can be applied to the characteristics of education 4.0 today. In addition, no one has researched the NKRP manuscript and the writing is still good and can still be read clearly.

The manuscript contains the concept of a good leader, such as a leader who is fair, kind, compassionate, obedient to God, and can lead and solve various problems [6]. That all kings have diverse leadership personalities in order to protect their people [7]. In addition, Sunan Paku Buwana IV described the leadership pattern in the Wulang Reh manuscript.

This study describes the personality of Javanese leaders based on the Wulang Reh pupuh mijil manuscripts, on 1 to 3 and Pupuh Asmaradana on 11 to 14. In the Wulang Reh manuscripts it is explained that the personality of a good Javanese leader is wise, patient, smart in all things, responsible, compassion, fairness, tolerance, trust. The personality of the Javanese leader, of course, will be very useful when applied to leadership at this time, namely in the era of 4.0.

This study aims to explain the personality of Javanese leaders contained in the NKRP manuscript. The benefits and importance of conducting this research is to help readers to know more about the personality of Javanese leaders in the NKRP manuscript and to add leadership knowledge that can be applied to the characteristics of education 4.0.

\subsection{Philology}

Philology is a literary science that has a broad meaning that includes the fields of language, literature, and culture [3]. Philology focuses on texts and manuscripts as objects. In this study, the manuscript used as the object of research is the NKRP manuscript. Then the text used in this study is the text or content in the NKRP manuscript. That every science has an object of research. As described above, philology has research objects in the form of manuscripts and texts [3].

\subsection{Personality Psychology}

The first goal of personality psychology is to obtain information about human behavior [8]. A person's behavior is only the cover; the outer part of himself. This shows that in order to know more deeply about a person's personality, a special behavior must be seen.

Personality is dynamic, not static without changing [9]. Personality shows behavior that develops and as a behavior between what the person brings with the place. A person's personality has distinctive characteristics, many characteristics that can distinguish that person from other people.

\subsubsection{Personality Aspects of Javanese Leaders}

In the Wulang Reh manuscript, Pupuh Mijil describes Javanese leadership. In pupuh mijil on 1 to 3 it reads " samia dipunemut jejering satriya punika kedah anteng jatmika ing budi, ruruh, wasis ing sabarang damel, sarta prawira lan weweka ing batin " [10]. From the article, it means that humans must remember that the knight (leader) must be wise, patient, smart in all things, responsible, and humble.

In the Wulang Reh manuscript in Pupuh Asmaradana on 11 to 14 it is written every action must always be done consciously, use tolerance, trust in government and do not abuse power [10]. Have compassion, be fair in dividing the work in each position, show goodness and truth when someone makes a mistake, weigh the situation with his fault; The aim is not to be arbitrary when action. When giving a punishment or reward, don't break it and must be even. From the explanation of the Wulang Reh manuscript, it is concluded that a good Javanese leader must have a personality such as being wise, patient, smart in all things, responsible, compassionate, fair, tolerant, and trustworthy.

\section{RESEARCH METHOD}

\subsection{Type of Research}

This research uses descriptive research methods and philological research methods, because in this study, the data collected are in the form of words. The implementation of philological research on manuscripts and texts was carried out by conducting research work steps [2]. The work steps of philological research are (1) determination of manuscripts and texts with a catalog study, (2) inventory of manuscripts and texts, (3) descriptions of manuscripts and texts, (4) transcribing of texts, (5) comparison of manuscripts and texts, (6) text editing, (7) text translation, and also (8) text analysis. 


\subsection{Data and Data Sources}

The data as the object of research in this study is the content contained in the NKRP manuscript. The NKRP manuscript is one of the collections of the Sonobudoyo library with the code PB C. 71. The NKRP manuscript was copied on 27 March 1935 with a total of 27 pages. The NKRP manuscript was written using the song Macapat Sinom, totaling 63 stanzas in handwriting. The NKRP manuscript also uses Javanese script and uses the Javanese language. Thus, it is necessary to convert the script to Latin script or transliterate steps to make it easier for readers to understand the contents of the NKRP manuscript. Furthermore, the source of data that is the subject of research in this study is the NKRP manuscript.

\subsection{Data Analysis Techniques}

This research, of course, uses data analysis techniques. The data analysis technique used is descriptive analysis as well as heuristics and literary hermeneutics. The data analysis technique by means of descriptive analysis is in accordance with the research objective, namely to explain the personality of Javanese leaders in the NKRP manuscript. The data analysis technique in this study has four steps, namely (1) data reduction, (2) data classification, (3) data display, (4) interpretation [11]. The next data analysis technique is using heuristic and hermeneutic steps. Heuristic and hermeneutic steps were used to determine the personality of Javanese leaders in the NKRP manuscript. Heuristic steps to find the meaning of lingual units based on the Bausastra dictionary. Meanwhile, the hermeneutic step is used to find the meaning implied in the manuscript, so that the personality of the Javanese leader can be found in the NKRP manuscript.

\subsection{Data Validity}

The validity of the data in this study is to use validity and reliability. The validity used in this study is semantic validity. By using semantic validity, the data in the NKRP manuscript in the form of stanzas from the song Sinom can be defined according to the context. While the reliability used in this study is intrarater reliability. Intrarater reliability is done by reading the text of the NKRP manuscript repeatedly so that it gets the same data.

\section{RESEARCH RESULTS}

The results of this study are to explain the personality of Javanese leaders based on the Wulang Reh manuscript. The personality of the Javanese leader in the Wulang Reh manuscript is wise, patient, smart in all things, responsible, compassionate, fair, tolerant, trustworthy.

In this study, it was found that the personality of the first Javanese leader was wise. Wise personality in the NKRP manuscript found 4 data. One of the figures who has a wise personality in the NKRP manuscript is Patih Cakrajaya with data number P.25/SNKRP/g.9. The stanzas of the song written in the manuscript are as follows.
//gugul kapelaking yuda
wadyanira hanglolosi
mung kari garwa lan putra
Pangeran anglesing galih
dadakaning pamikir
mung nedya anungkul
mring patih cakrajaya

kang tugur pring Surawesthi

wus utussan tinampan panungkulira/l

In the passage above shows that Cakraningrat 3 has sent an ambassador to Patih Cakrajaya in Surabaya and the reporting of his defeat has been received. From gatra "wus utusan tinampan panungkulira" it can be concluded that Patih Cakrajaya has a wise personality because of accepting the defeat of Cakraningrat 3 .

The second personality of the Javanese leader is patient. Patient personality in the NKRP manuscript found 12 data. One of the characters who has a patient personality in the NKRP manuscript is Gusti Kanjeng Sekaring Puri with data number P.4/SNKRP/g.8. The stanzas of the song written in the manuscript are as follows.

//miyos wanudya utama
sor rarasing surapsari
sinung jujuluk sang retna
Gusti jeng Sekaring Puri
ambek ngumala manik
kalokeng jagad linuhung
wahdat lan narsa krama
sor tapaning pra maharsi
nadyan putri dadya raksakaning praja//

The passage above shows that Gusti Kanjeng Sekaring Puri has a patient personality because she is able to suffer and much pray and praise God. Thus, in 
the NKRP manuscript written "sor tapaning pra maharsi" as a representation that Gusti Kanjeng Sekaring Puri is very serious in prayer and able to suffer. His worship is better than the priest's worship.

The third personality of the Javanese leader is smart. Smart personality in the NKRP manuscript found 4 data. One of the figures who has a smart personality in the NKRP manuscript is Wira Utama 2 with data number P.37/SNKRP/g.3. The stanzas of the song written in the manuscript are as follows.

\section{//punika lajeng puputra}

Wira utama ping kalih

sarjana tur parikrama

puputra alus kang budi

sumilih Adipati

wira utama ping telu

puputra salin nama

\section{Surautama prajurit}

apuputra Dipati Warga utama//

The passage above shows that Wira Utama 2 has a smart personality. The third "gatra" or line "sarjana tur parikrama" means that Wira Utama 2 is a smart and politene person.

The fourth personality of the Javanese leader is responsibility. Personality of responsibility in the NKRP manuscript found 4 data. One of the figures who has a responsible personality in the NKRP manuscript is Adipati Warga Utama with data number P.40/SNKRP/g.3. The stanzas of the song written in the manuscript are as follows.

//kacarita duk jeng Sultan
amundhut rara wuragil
ingaturken priyongga
Warga utama Dipati
maring Pajang nagari
dahat sukeng tyas sang PraBu
dupi antara dina
nyuwun pamit den lilani
wus samapta bidhal sawadya balanya//

The passage above shows that Adipati Warga Utama has a responsible personality. From gatra 3 "ingaturken priyongga“", it means that Adipati Warga Utama delivered his daughter to Pajang. It shows that he carries out the responsibility of a parent to deliver his daughter to the king of Pajang without ordering his servant.
The fifth personality of the Javanese leader is compassion. Compassionate personality in the NKRP manuscript found 9 data. One of the figures who has a compassionate personality in the NKRP manuscript is Arya Damar with the data number P.9/SNKRP/g.3. The stanzas of the song written in the manuscript are as follows.

//sinung nama arya damar
ngibawa sasat Narpati
suyut praja kering Kanan
kasoran prabawa sakti
kangreh kang nungkul aris
pinreping dana martayu
garwa paringing rama
putri sing sina nagari
apuputra raden menak sunaya//

The passage above shows Arya Damar as a compassionate person in the kraton. From the third gatra "suyut praja kering Kanan", it can be concluded that Arya Damar has a compassionate personality around the kraton.

The sixth personality of the Javanese leader is just. Fair personality in the NKRP manuscript found 1 data. The name of the leader in the data is Jaka Kahiman with the data number P.56/SNKRP/g.8. The stanzas of the song written in the manuscript are as follows.

//yata kang madeg Dipatya
langkung wlas sira kang wresni
kembet dosaning sudarma
antuk dudukaning aji
mangkana Sang Dipati
amrih utameng tumuwuh
siti ing wirasaba
pinara sakawan adil
ipe kalih lan paripeyan satunggal//

The excerpts above show that Jaka Kahiman has a fair personality. From gatra 8 which says "pinara sakawan adil" means that Jaka Kahiman is a fair person because of his attitude that can divide his parent-in-law legacy to his four brother-in-laws.

The seventh personality of the Javanese leader is tolerance. Tolerance personality in the NKRP manuscript found 1 data. The name of the leader in the data is Jaka Kahiman with the data number P.56/SNKRP/g.6-8. 


\author{
//yata kang madeg Dipatya \\ langkung wlas sira kang wresni \\ kembet dosaning sudarma \\ antuk dudukaning aji \\ mangkana Sang Dipati \\ amrih utameng tumuwuh \\ siti ing wirasaba \\ pinara sakawan adil \\ ipe kalih lan paripeyan satunggal//
}

The passage shows that Jaka Kahiman not only has a fair personality, but also has a tolerant personality. Wroten in gatra 6 "amrih utameng tumuwuh", gatra 7 "siti ing wirasaba" and gatra 8 "pinara sakawan adil", it is mentioned that although he had positioned as the representative of Sultan Hadiwijaya, but he can tolerant to divide his territory to his four brother.

The eighth personality of the Javanese leader is amanah. There are 6 data found in the trustworthy personality in the NKRP manuscript. One of the figures who have a trustworthy personality in the NKRP manuscript is a follower of Sultan Hadiwijaya with the data number is P.54/SNKRP/g.9. The stanzas of the song written in the manuscript are as follows.

//bebed rejeng tan linilan
myang neng waton amben linggih
miwah samubarang karya
nyingkirana sabtu pahing
tumrahing wuri wuri
denya cawuhken bebendu
rejeng nyanyampingira
nuju dina sabtu pahing
yata wau gandhek wus matur jeng Sultan//

The passage shows that the messenger of Sultan Hadiwijaya has a trustworthy personality. From the gatra " yata wau gandhek wus matur jeng Sultan ", it is explained that the messenger carry out the orders. Sultan Hadiwijaya's messenger has a trustworthy personality because he has reported his message honestly.

\section{CONCLUSION}

Based on the discussed results, this article can conclude that the personality of the Javanese leaders can be found in the NKRP manuscript. Such personality of the Javanese leaders is explained based on the Wulang Reh manuscript. The personality of the Javanese leader in the Wulang Reh manuscript is wise, patient, smart in all things, responsible, compassionate, fair, tolerant, trustworthy. In the NKRP manuscript, it is found wise, patient, smart in all things, responsibility, compassion, fairness, tolerance, and trust.

The implication that can be learned from the results of research on the personality of Javanese leaders in the NKRP manuscript is probably today's life exemplary behavior of our leaders. Furthermore, the results of this study can add knowledge and insight about character education that can be used in learning. The personality of these exemplary Javanese leaders can be role models in everyday life until today.

\section{REFERENCES}

[1] S. Muhamad, Membingkai kajian historis dan filologis dalam penelitian ilmiah. Banten: IAIN Sultan Maulana Hasanuddin Banten, 2015.

[2] N. Endang, dkk, Dunia manuskrip jawa. Yogyakarta: Cantrik Pustaka, 2018.

[3] B. S. Baroroh, dkk, Pengantar teori filologi. Jakarta: Pusat Pembinaan dan Pengembangan Bahasa Departemen Pendidikan dan Kebudayaan, 1985.

[4] N. Endang, dkk, The effectiveness of Game-based learning model in the javanese language class. Humanities \& Social Sciences Reviewse, 2020, ISSN: 2395-6518, Vol 8, No 2, 2020, pp 652-660. DOI:http://doi.org/10.18510/hssr.2020.8273.

[5] F. Reli, dkk, Jurnal : Kontribusi Penelitian Filologi Untuk Pengembangan Studi Sejarah, Bandung: Universitas Pajajaran, 2018, DOI: http://www.jurnal.uinbanten.ac.id/index.php/tazkiy a/article/view/213

[6] S. Bani, Jurnal: Sumbangan filologi dalam penyusunan strategi kebudayaan indonesia. Surakarta: Universitas Sebelas Maret Surakarta, 2007.

[7] N. Endang, dkk, Leadreship education of javanese king's character in serat wulang reh. Jour of Adv Research in Dynamical \& Control Systems, 2019, DOI: $10.5373 / J A R D C S / V 11 S P 12 / 20193224$.

[8] M. Albertine, Psikologi sastra, Jakarta: Yayasan Pustaka Obor Indonesia. 2010.

[9] P. Ngalim, Psikologi pendidikan, Bandung: PT Remaja Rosdakarya, 1991.

[10] Darusuprapta, Serat wulang reh, Surabaya: Citra Jaya. 1982.

[11] Kaelan, Metode penelitian kualitatif bidang filsafat, Yogyakarta: Paradigma, 2005. 